\title{
Study of the influence of intermittent motion on the orientation kinematic precision of a double harmonic transmission
}

\begin{abstract}
Sava Ianici, Draghiţa Ianici*
The paper presents a method and an experimental installation, designed by the authors, for determining the orientation kinematic precision of a double harmonic transmission (DHT). The influence of repeated stops and then continued motion on the orientation kinematic precision of the DHT was researched. The study of the orientation kinematic precision of DHT was performed by taking into account 5 torque steps of DHT, at a constant speed of the driving shaft and maintaining its same direction of rotation. Experimental investigations have shown that the instantaneous transmission ratio of the DHT does not vary significantly from its nominal value and that the orientation kinematic precision of DHT decreases with increasing transmission torque.
\end{abstract}

Keywords: double harmonic transmission, transmission ratio, kinematic error, orientation kinematic precision

\section{Introduction}

The main trend of the current stage of modernization of the technical industry is the robotization and automation of production processes, through the implementation of industrial robots and the integration of systems commanded and coordinated by computing units. The kinematic performances of the industrial robots are identified, mainly, by the precision of the mechanical movements executed by their elements [1-5].

In this context, the importance of modern gear transmissions has increased, compared to traditional ones, due to the advantages they have in ensuring a precise rotational motion. DHT is included in this category of so-called "unconventional" or "modern" transmissions. DHT it has a number of advantages over other gear 
transmissions, namely: high transmission ratio, high kinematic precision of orientation and repeatability, small gauge and mass, self-balanced, low moments of inertia and extremely small clearance, compact and coaxial construction [6-11].

Starting from these aspects, within the Department of Engineering Sciences at the Faculty of Engineering and Management from Resita, a series of researches have been carried out over the years on the structure, kinematics, geometry and dynamics of double harmonic transmissions [12-14].

In the reference [15], the authors presented the results of experimental research conducted in order to determine the kinematic positioning accuracy of DHT. Thus, the influences of the variation of the transmission load, respectively of the reversal of the direction of rotation of the input shaft on the transmission ratio and of the kinematic positioning accuracy of DHT were studied.

This paper is a continuation of this research, the authors aiming to study the influence of the intermittent movement of the input shaft on the orientation kinematic precision of DHT.

\section{Calculation of the orientation kinematic error of DHT}

The double harmonic transmission (figure1) is used in the following constructive structure: cam wave generator (1), flexible wheel (2), fixed rigid wheel (3) and mobile rigid wheel (4).

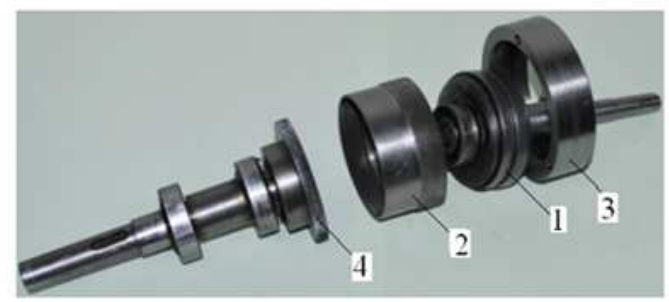

Figure 1. The constructive structure of the DHT

The input element of the DHT is the wave generator (1) which deforms the short flexible wheel (2), so that it will have four equidistant engagement areas, two with fixed rigid wheel (3 - which is provided with the inner teeth and others two with the output element represented by the mobile rigid wheel (4 - which is provided with the outer teeth.

Presence in the structure of DHT of a deformable element (flexible wheel) leads to the appearance of a own kinematic error of the transmission. In addition to this, errors can also occur due to improper execution and incorrect mounting of the gear wheels. 
The orientation kinematic precision of DHT was evaluated by the positioning error of the driven element of the transmission. The positioning kinematic error (also called orientation kinematic error) was defined as the difference between the effective and the theoretical rotation angle of the transmission output shaft.

The calculation methodology of the orientation kinematic error of DHT is based on the following successive stages:

- calculation of transmission ratio of the DHT:

$$
i_{14}^{(3)}=\frac{z_{2} \cdot z_{4}}{z_{2} \cdot z_{4}-z_{2}^{\prime} \cdot z_{3}}
$$

where: $z_{2}, z_{2}^{\prime}, z_{3}, z_{4}$ are the numbers of teeth of the wheels.

- calculation of the theoretical rotation angle of the driven element of the DHT:

$$
\varphi_{4 t}=\frac{\varphi_{1}}{i_{14}^{(3)}}
$$

where: $i_{14}^{(3)}$ is the theoretical transmission ratio of the DHT, $\varphi_{1}$ - the rotation angle of the wave generator.

- calculation of the orientation kinematic error of DHT:

$$
\Delta \varphi=\varphi_{4 r}-\varphi_{4 t}
$$

where: $\Delta \varphi$ is the orientation kinematic error; $\varphi_{4 \mathrm{r}}, \varphi_{4 \mathrm{t}}$ - the effective rotation angle of the driven element, respectively the theoretical one.

\section{Construction of the experimental installation}

In figure 2 shows the experimental installation used to investigate the orientation kinematic precision of researched DHT.

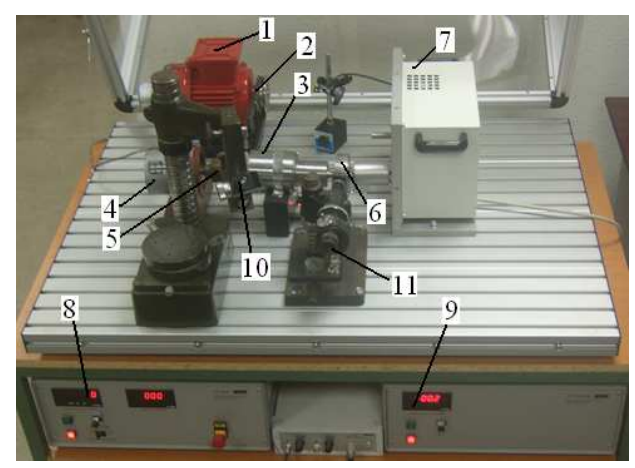

Figure 2. Construction of the experimental installation 
The experimental installation consists of: 1 - the asynchronous electric motor, 2 - the transmission with narrow trapezoidal belt, 3 - the double harmonic transmission, 4 - the incremental position transducer, 5 - the elastic coupling, 6 the divided disk, 7 - the brake with magnetic particles, 8,9 - the diagnostic systems and 10,11 - the optical systems for direct reading of the rotation angles of the transmission shafts.

\section{Research and experimental results}

The experimental research aimed to study the influence of repeated stops and starts of DHT on the transmission ratio and the orientation kinematic error of its.

Experimental research was performed on a DHT, with the following parameters: transmission ratio, $i_{14}^{(3)}=48.2$; the number of teeth of the wheels, $\mathrm{z}_{2}=$ 200 teeth, $z_{3}=202$ teeth, $z_{2}^{\prime}=190$ teeth and $z_{4}=188$ teeth.

The measurements of the rotation angles of the shafts was done by considering 5 loading steps of the transmission $\left(\mathrm{M}_{\mathrm{t}}=0 ; 2 ; 5 ; 7.5 ; 10 \mathrm{Nm}\right)$ and maintaining a constant input speed $\left(\mathrm{n}_{1}=500 \mathrm{rpm}\right)$ and the same direction of rotation.

The results obtained by recording the values of the rotation angle of the DHT output shaft and performing the related calculations are presented in Table 1.

Table 1. The orientation kinematic error

\begin{tabular}{|c|c|c|c|c|c|c|c|}
\hline \multirow{2}{*}{$\begin{array}{c}\text { Torque } \\
\mathrm{M}_{\mathrm{t} 4}[\mathrm{Nm}]\end{array}$} & \multicolumn{3}{|c|}{ Rotation angle $\varphi_{4}\left[{ }^{\circ},,^{\prime \prime}\right]$} & \multirow{2}{*}{$\begin{array}{l}\text { Angle } \\
\varphi_{1}\left[^{\circ}\right]\end{array}$} & \multirow{2}{*}{$\begin{array}{c}\text { Tran. ratio } \\
\mathrm{i}_{14}\end{array}$} & \multirow{2}{*}{$\begin{array}{c}\text { Mediate } \\
\mathrm{i}_{14}\end{array}$} & \multirow{2}{*}{$\begin{array}{c}\text { Kin. error } \\
\Delta \varphi\left[{ }^{\prime}\right]\end{array}$} \\
\hline & initial & final & real & & & & \\
\hline \multirow{4}{*}{0} & $0^{\circ} 2^{\prime \prime} 12^{\prime \prime}$ & $93^{\circ} 23^{\prime} 42^{\prime \prime}$ & $93^{\circ} 21^{\prime} 30^{\prime \prime}$ & 4500 & 48.2013 & \multirow{4}{*}{48.2015} & \multirow{4}{*}{13.335} \\
\hline & $93^{\circ} 23^{\prime} 42^{\prime \prime}$ & $186^{\circ} 45^{\prime} 06^{\prime \prime}$ & $93^{\circ} 21^{\prime} 24^{\prime \prime}$ & 9000 & 48.2017 & & \\
\hline & $186^{\circ} 45^{\prime} 06^{\prime \prime}$ & $280^{\circ} 06^{\prime} 35^{\prime \prime}$ & $93^{\circ} 21^{\prime} 29^{\prime \prime}$ & 13500 & 48.2016 & & \\
\hline & $280^{\circ} 06^{\prime} 35^{\prime \prime}$ & $373^{\circ} 27^{\prime} 57^{\prime \prime}$ & $93^{\circ} 21^{\prime} 22^{\prime \prime}$ & 18000 & 48.2018 & & \\
\hline \multirow{4}{*}{2} & $0^{\circ} 00^{\prime} 36^{\prime \prime}$ & $93^{\circ} 21^{\prime} 12^{\prime \prime}$ & $93^{\circ} 20^{\prime} 36^{\prime \prime}$ & 4500 & 48.2091 & \multirow{4}{*}{48.2097} & \multirow{4}{*}{79.335} \\
\hline & $93^{\circ} 21^{\prime} 12^{\prime \prime}$ & $186^{\circ} 41^{\prime} 39^{\prime \prime}$ & $93^{\circ} 20^{\prime} 27^{\prime \prime}$ & 9000 & 48.2097 & & \\
\hline & $186^{\circ} 41^{\prime} 39^{\prime \prime}$ & $280^{\circ} 01^{\prime} 49^{\prime \prime}$ & $93^{\circ} 20^{\prime} 10^{\prime \prime}$ & 13500 & 48.2197 & & \\
\hline & $280^{\circ} 01^{\prime} 49^{\prime \prime}$ & $373^{\circ} 21^{\prime} 57^{\prime \prime}$ & $93^{\circ} 20^{\prime} 08^{\prime \prime}$ & 18000 & 48.2113 & & \\
\hline \multirow{4}{*}{5} & $0^{\circ} 01^{\prime} 18^{\prime \prime}$ & $93^{\circ} 21^{\prime} 10^{\prime \prime}$ & $93^{\circ} 19^{\prime} 52^{\prime \prime}$ & 4500 & 48.2154 & \multirow{4}{*}{48.2139} & \multirow{4}{*}{132.035} \\
\hline & $93^{\circ} 21^{\prime} 10^{\prime \prime}$ & $186^{\circ} 40^{\prime} 32^{\prime \prime}$ & $93^{\circ} 19^{\prime} 22^{\prime \prime}$ & 9000 & 48.2175 & & \\
\hline & $186^{\circ} 40^{\prime} 32^{\prime \prime}$ & $280^{\circ} 59^{\prime} 40^{\prime \prime}$ & $93^{\circ} 19^{\prime} 08^{\prime \prime}$ & 13500 & 48.2189 & & \\
\hline & $279^{\circ} 59^{\prime} 40^{\prime \prime}$ & $373^{\circ} 19^{\prime} 08^{\prime \prime}$ & $93^{\circ} 19^{\prime} 28^{\prime \prime}$ & 18000 & 48.2189 & & \\
\hline \multirow{4}{*}{7.5} & $0^{\circ} 01^{\prime} 35^{\prime \prime}$ & $93^{\circ} 20^{\prime} 25^{\prime \prime}$ & $93^{\circ} 18^{\prime} 50^{\prime \prime}$ & 4500 & 48.2243 & \multirow{4}{*}{48.2235} & \multirow{4}{*}{179.335} \\
\hline & $93^{\circ} 20^{\prime} 25^{\prime \prime}$ & $186^{\circ} 39^{\prime} 13^{\prime \prime}$ & $93^{\circ} 18^{\prime} 48^{\prime \prime}$ & 9000 & 48.2244 & & \\
\hline & $186^{\circ} 39^{\prime} 13^{\prime \prime}$ & $279^{\circ} 57^{\prime} 45^{\prime \prime}$ & $93^{\circ} 18^{\prime} 32^{\prime \prime}$ & 13500 & 48.2252 & & \\
\hline & $279^{\circ} 57^{\prime} 45^{\prime \prime}$ & $373^{\circ} 16^{\prime} 16^{\prime \prime}$ & $93^{\circ} 18^{\prime} 31^{\prime \prime}$ & 18000 & 48.2257 & & \\
\hline \multirow{4}{*}{10} & $0^{\circ} 00^{\prime} 16^{\prime \prime}$ & $93^{\circ} 18^{\prime} 14^{\prime \prime}$ & $93^{\circ} 17^{\prime} 58^{\prime \prime}$ & 4500 & 48.2317 & \multirow{4}{*}{48.2270} & \multirow{4}{*}{209.335} \\
\hline & $93^{\circ} 18^{\prime} 14^{\prime \prime}$ & $186^{\circ} 36^{\prime} 24^{\prime \prime}$ & $93^{\circ} 18^{\prime} 10^{\prime \prime}$ & 9000 & 48.2309 & & \\
\hline & $186^{\circ} 36^{\prime} 24^{\prime \prime}$ & $279^{\circ} 54^{\prime} 42^{\prime \prime}$ & $93^{\circ} 18^{\prime} 18^{\prime \prime}$ & 13500 & 48.2302 & & \\
\hline & $279^{\circ} 54^{\prime} 42^{\prime \prime}$ & $373^{\circ} 12^{\prime} 57^{\prime \prime}$ & $93^{\circ} 18^{\prime} 15^{\prime \prime}$ & 18000 & 48.2300 & & \\
\hline
\end{tabular}

Figure 3 shows the variation diagram of the instantaneous transmission ratio, and in figure 4 is presented the orientation kinematic error diagram of the DHT. 


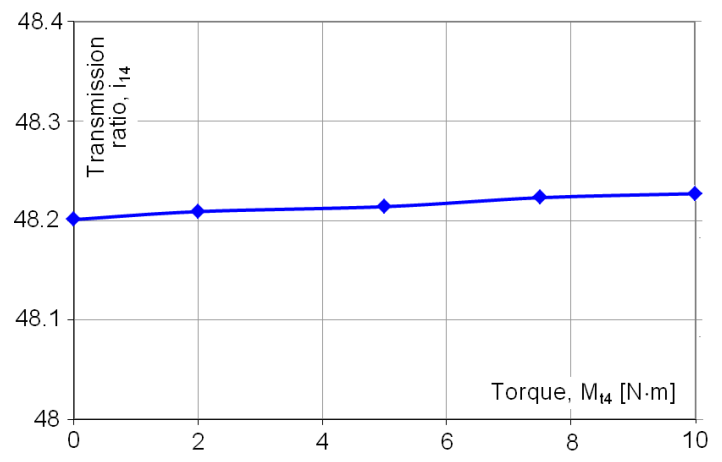

Figure 3. Transmission ratio of the DHT

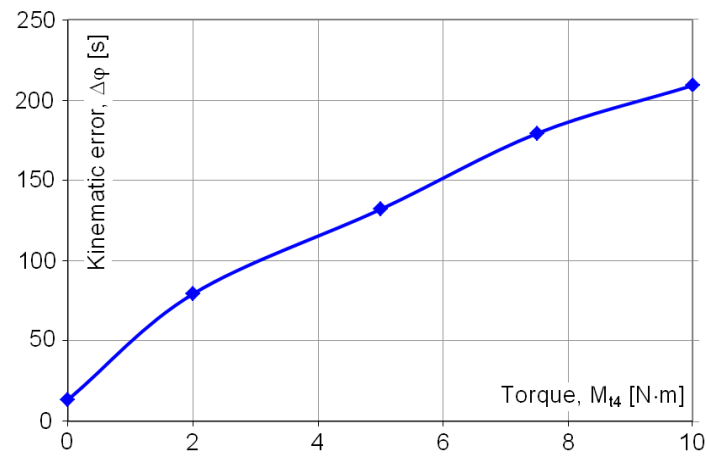

Figure 4. Kinematic error of orientation of the DHT

\section{Conclusion}

The paper presents a method of experimental determination of the orientation kinematic error of the DHT. The influence of repeated stops and continuations of motion on the orientation kinematic precision of DHT was studied.

The experimental tests were performed on a DHT with a short flexible wheel and consisted in measuring and recording the rotation angle of the output shaft for different angles of rotation of the input shaft.

From the analysis of the results of the experimental tests it was found that by repeated stops and starts, in the same direction, for the same torque, the transmission ratio of the DHT does not change significantly compared to the nominal value $\left(i_{14}^{(3)}=48.2\right)$. It was also found that as the DHT torque increases, there is an increase in the orientation kinematic error of the DHT output shaft, thus at $\mathrm{M}_{\mathrm{t}}=0$ $\mathrm{N} \cdot \mathrm{m}$ it was obtained $\Delta \varphi=13.3^{\prime \prime}$ and at $\mathrm{M}_{\mathrm{t} 4}=10 \mathrm{Nm}$ it was obtained $\Delta \varphi=209.3^{\prime \prime}$. 


\section{References}

[1] Ianici S., Ianici D., Elemente de inginerie mecanică, Universitatea Eftimie Murgu Reşiţa, 2015.

[2] Frolov K.V.,Vorobiev V.I., Mehanika promîşlienîh robotov, vol. 1, 2, 3, Izd. Vîsşaia Şkola, 1988/1989.

[3] Miloiu G., Transmisii mecanice moderne, Ed. Tehnică, 1980.

[4] Bostan I., Dulgheru V., Grigoraş S., Transmisii planetare, precesionale şi armonice, Ed. Tehnică, 1997.

[5] Kovalev N.A., Peredaci ghibkimi kolesami, Izd. Maşinostroenie, 1979.

[6] Ivanov M.N., Volnovîe zubciatîe peredaci, Izd. Vîsşaia Şkola, 1981.

[7] Istomin S.N., Kinematiceskaia tocinost pribornîh volnovîh peredaci, Izd. Maşinostroenie, 1987.

[8] Litvin F.L., Gear geometry and applied theory, PTR Prentice Hall, 1994.

[9] Ghinzburg G., Volnovîe zubciatîe peredaci, Izd. Maşinostroenie, 1977.

[10] Harachová D., Solution and modification in the profile the harmonic drive, GRANT Journal, 2014, pp. 73-76.

[11] Dong H., Zhu Z., Zhou W., Chen Z., Dynamic simulation of harmonic gear drives considering tooth profile parameters optimization, Journal of Computers, 7(6), 2012, pp. 1429-1436.

[12] Ianici D., Ianici S., Dynamic research of the flexible wheel of a double harmonic gear transmission, Analele Universităţii „Eftimie Murgu” Reşiţa, Fascicula de Inginerie, 22(1), 2015, pp. 223-230.

[13] Ianici S., Contributions on determining the forces distributions in the toothed harmonic drive (THD), The $8^{\text {th }}$ Symposium International Mechanisms and Mechanical Transmissions - MTM 2000, Timisoara, Romania, pp. 165-168.

[14] Ianici S., Vela I., Ianici D., Micloşină C.O., Double harmonic transmission used in industrial robotic drives, Proceedings of the $2^{\text {nd }}$ International Conference on Robotics, Oct. 14-16, 2004, Timişoara, Romania, pp. 89-90.

[15] Ianici S., Ianici D., Experimental determination of kinematic precision of positioning of a double harmonic transmission, Analele Universităţii „Constantin Brâncuşi” din Târgu Jiu”, Seria Inginerie, nr. 2, 2019, pp. 139-144.

Addresses:

- Prof. Dr. Eng. Sava Ianici, Babeș-Bolyai University, Faculty of Engineering, Piaţa Traian Vuia, nr. 1-4, 320085, Reşiţa, s.ianici@uem.ro

- Lect. Dr. Eng. Draghiţa Ianici, Babeș-Bolyai University, Faculty of Engineering, Piaţa Traian Vuia, nr. 1-4, 320085, Reşiţa, d.ianici@uem.ro (*corresponding author) 